\title{
What Does Research Tell Us about Trends in Dissertations on PBL?
}

\author{
Tolga Erdogan
}

Army NCO Vocational College, National Defense University, Turkey

Copyright $(2017$ by authors, all rights reserved. Authors agree that this article remains permanently open access under the terms of the Creative Commons Attribution License 4.0 International License

\begin{abstract}
The aim of this study is to investigate the research trends in dissertations on PBL from 2002 to 2015 in Turkey. For this purpose, the master's and doctorate dissertations in the National Thesis Database of Council of Higher Education (CoHE) were selected for rigorous content analysis. The analysis was utilized to classify the type of study, the learning domains, research methods, research designs, research domains, subject groups, group sizes, length of treatments and data collection instruments. For analysis purposes, frequencies and percentages were calculated for each category. Additionally, the results obtained in these dissertations were examined and reported separately with regards to cognitive, affective and conative domains. According to analysis results; science is the most favorable learning domain, quantitative methodology is more utilized as compared to qualitative and quantitative methods, cognition and affect followed by cognition only are the mostly utilized research domains, subject groups are predominantly at elementary education level and secondly from teacher education, studies preferred to have a group size of 41-80, the treatments on PBL research last mostly four to six weeks, and finally majority of the studies use achievement tests and attitude scales as instruments of measurement.
\end{abstract}

Keywords Problem-based Learning, Content Analysis, Research Trends, PBL Dissertations, Cognition, Affect and Conation

\section{Introduction}

The Turkish education system, which is under the supervision and control of the Ministry of National Education (MoNE), consists of three levels which make up 12 years of compulsory education: The elementary school education (grades 1-4), the middle school education (grades
5-8), and the high school education (grades 9-12). Students who graduate from high schools have the right to continue to higher education, which is governed by the Council of Higher Education (CoHE) and includes universities, institutes of technology, vocational schools, and other higher education institutions such as military academies and colleges.

Starting in the 2005-2006 Academic Year, constructivist teaching and learning was introduced into elementary and secondary education and curricula were changed accordingly. The main aim was to assure that each pupil's social, psychological and moral development reach to the desired level and to give students a chance to apply what they have learned, to urge them use higher order thinking skills more and to train students as lifelong learners (MoNE, www.meb.gov.tr). With the onset of constructivism in Turkish education system, research started to focus on methodologies such as project-based learning, inquiry-based learning, case-based learning, etc., which embody the principles of constructivist teaching and learning [1].

Problem-based learning (PBL) is one of those constructivist teaching and learning methodologies implemented in schools and investigated in current research in Turkey. Literature review on PBL studies suggests that the majority of PBL research and practice is in higher education, specifically medical education, but recently more research has been published in different disciplines and levels [2, 3]. Outside Turkey, many meta-analyses and reviews $[3,4,5,6$, $7,8,9,10,11,12]$ have been conducted to analyze the effectiveness of PBL. The only meta-analysis on PBL research in Turkey, which could be accessed by the author as of October 2014, belongs to Üstün [13]. It is quite obvious that more review studies are needed to analyze PBL's appropriateness, its application and practices, its strengths and weaknesses, and its potential influence on today's education [14], specifically in Turkey. Besides, as more disciplines and educational settings (e.g. elementary education, higher education) began experimenting with PBL, it became necessary to review the outcomes reported in these 
studies. Therefore, reviewing the research trends in PBL studies may help the researchers in related fields to identify their research interests and designs.

In this respect, this study intends to investigate the research trends in dissertations on PBL from 2002 to 2015 in Turkey. For this particular purpose, the master's and doctorate dissertations in the National Thesis Database of CoHE were selected for analysis. The research questions addressed by this paper include:

1. What type of studies, learning domains, research methods, research designs, research domains, subject groups, group sizes, length of treatments and data collection instruments were used in the selected theses from 2002 to 2015 ?

2. What were the findings of these studies regarding cognitive, affective and conative domains?

Apart from the research questions above, the author aims to present a critical analysis of the methodologies used and provide implications for further practice and research on PBL in the discussion part.

\subsection{Problem-Based Learning (PBL)}

PBL is a student-centered, inquiry-based approach, which has its roots in constructivist epistemology [15] and begins with an ill-structured problem with possible multiple solutions. Teachers are facilitators, whereas learners actively construct knowledge by defining learning goals, seeking information to build upon prior knowledge, reflecting on the learning process, and participating actively in cooperative/collaborative learning groups $[16,17,18]$. Barrows [19] identifies the following objectives of problem-based learning:

- Structuring of knowledge for use in clinical contexts,

- The development of an effective clinical reasoning process,

- The development of effective self-directed learning (SDL) skills,

- Increased motivation for learning (p. 481-482).

Among the educational objectives and goals listed above, value is placed on PBL's promotion of learning outcomes in the cognitive, affective, and conative domains. Huitt and Cain [20] define;

- Cognition as a reference to the process of coming to know and understand; of encoding, perceiving, storing, processing, and retrieving information. It is generally associated with the question of "what" (e.g., what happened, what is going on now, what is the meaning of that information).

- Affect as a reference to the emotional interpretation of perceptions, information, or knowledge. It is generally associated with one's attachment (positive or negative) to people, objects, ideas, etc. and is associated with the question "How do I feel about this knowledge or information?".
- Conation as a reference to the connection of knowledge and affect to behavior and is associated with the issue of "why." It is the personal, intentional, planned, deliberate, goal-oriented, or striving component of motivation, the proactive (as opposed to reactive or habitual) aspect of behavior.

The references to cognitive, affective, and conative domains of learning above presents PBL's potential to promote not only what is learned, but also put emphasis on feelings on what is learned and the learning experience itself, together with willingness and desire to learn. Investigating the dissertations with regards to the findings related to these domains would help practitioners and researchers in their studies.

\subsection{Review of PBL Research}

Review studies on PBL are predominantly in medical education; however, the adoption of this particular method has extended into elementary schools, secondary schools, universities of different disciplines, and professional schools. In his review, Savery [2] gives a list of several studies, which illustrates the multiple contexts where PBL instructional approach is being utilized.

Previous meta-analyses and reviews $[4,5,6,7,8,9,10,11$, $13,12,3]$ have focused on various outcomes of PBL instruction.

Albanese and Mitchell [4] categorized and listed the qualitative results of studies in medical education from 1972 to 1993 . The main results of this review were that students held more positive views on PBL than traditional instruction and PBL graduates performed as well and sometimes better than traditional graduates on clinical examinations and faculty evaluations. However, PBL students scored lower on basic science examinations in comparison with their conventionally trained counterparts.

More recently, Dochy, Segers, Van den Bossche and Gijbels [7] reviewed studies on PBL beyond the domain of medical education. The results of their meta-analysis suggested that PBL had statistically and practically significant positive effects on students' knowledge application. The findings on knowledge base of students led the authors to conclude that students in PBL performed at least as well as students in conventional learning environments. The last remarkable finding related to the retention period was that students in PBL gained slightly less knowledge, but remembered more of the acquired knowledge.

In their meta-analysis, Gijbels, Dochy, Van den Bossche and Segers [8] investigated the assessment of three levels of the knowledge structure as main independent variable in PBL settings: (a) understanding of concepts, (b) understanding of the principles that link concepts and (c) linking of concepts and principles to conditions and procedures for application. They found that PBL had the most positive effects when the focal constructs being 
assessed were at the level of understanding principles that link concepts. The results suggested that the implications of assessment must be considered in examining the effects of PBL and probably in all comparative education research.

In their synthesis Vernon and Blake [12], analyzed all available research from 1970 to 1992. In their comparison of PBL with more traditional methods of medical education, they found that PBL was superior with respect to students' attitudes and opinions about their programs and with respect to measures of students' clinical performance. They also reported that contrary to the previous review findings, the scores of PBL students on various tests of factual and clinical knowledge were not significantly different from the scores of conventionally taught students. However, the conventionally taught students performed significantly better than their PBL counterparts on the National Board of Medical Examiners (NBME) Step 1, which focuses on concepts of basic science that are important to the practice of medicine, with special emphasis on principles and mechanisms underlying health, disease and methods of therapy.

Berkson [5] also searched for evidence of the effectiveness of PBL in medical education. The results showed no distinction between graduates of PBL and traditional instruction, considering problem solving, imparting knowledge, motivation to learn medical science, promoting self-directed learning skills, and student and faculty satisfaction. However, PBL was found to be stressful for both students and faculty.

In their meta-analytic study, Kalaian, Mullan and Kasim [9] indicated that PBL curricula showed higher performance on standardized profession-wide clinical science outcome measures, but lower on basic science outcome measures. Additionally, their findings suggested that schools which had a past history in PBL utilization, which had developed teaching expertise and learning materials for PBL instruction were able to score on basic science outcome measures as high as those schools which followed more traditional methods of instruction.

In his review Colliver [6] examined the educational superiority of PBL in comparison to traditional approaches. He concluded that there was no convincing evidence that PBL improved students' knowledge base or clinical performance. Nevertheless, he stated that PBL might provide a more challenging, motivating, and enjoyable approach to medical education.

In her study, Leary [10] conducted a meta-analysis across all disciplines to examine the extent to which problem-based learning engendered self-directed learning compared to a lecture-based approach. From her synthesis, she showed that PBL promoted conative and affective skills in self-directed learning.

In their review of empirical studies that examined Self-Directed Learning (SDL) and Self-Regulated Learning (SRL) in PBL environments, Loyens, Magda and Rikers [11] gave evidence on PBL's positive influence on the development of SDL and SRL, though the studies showed mixed results. They also concluded that more research was needed to better understand how, when, and why PBL fostered development of SDL and SRL.

In his meta-analysis of Turkish studies, Üstün [13] investigated the effectiveness of PBL on student achievement and motivation in science, together with its influence on attitudes towards science and skills in elementary, secondary and higher educational levels. Additionally he examined the effects of some moderator variables including publication type, research design, teacher effect, researcher effect, country, subject matter, school level, PBL mode, length of treatment, group size, type of questions and assessment instrument on the effectiveness of PBL. The results of 147 effect sizes he calculated from 88 primary studies included in his research clearly showed PBL's superiority over traditional teaching methods on different outcomes. More specifically, PBL had a huge impact with a large effect size of 0.820 on students' achievement in science subjects in different levels and revealed medium effect sizes of $0.566,0.616$, and 0.565 for students' attitude towards science, motivation in science and different kinds of skills respectively. Moreover, he reported that moderator analyses indicated noteworthy impact of publication type, country, subject area, school level and length of treatment on the effectiveness of PBL.

There is also a body of evidence derived from interviews and observations in related research on PBL. In summary, it was suggested that PBL granted students the chance to work on real life problems in their cooperative learning groups and supported student development by enhancing sharing of knowledge; PBL was well received and found useful both by the instructors and students; PBL enhanced the development of self-regulated learning skills of students better than their counterparts receiving traditional instruction; the interactions among students in PBL tutorials contributed substantially to group processes and performance outcomes; the ultimate gains of PBL classes were interaction and access to more information as a result of increased research skills; PBL students' reliance on their instructors' guidance decreased and they focused more on their peers' opinions and contributions; and PBL was influential in the development of group interactions, student self-reliance, research skill development and active participation during the learning process [21, 22, 23, 24, 25, 26, 27, 28, 29]. On the other hand, the workload of PBL tutorials was a common complaint among students and students' statements of uncertainty (what to learn, where to find, how to start etc.) at the beginning of PBL tutorials were some of the challenges noticed [30, 26].

The prior meta-analyses and reviews summarized above clearly suggest that PBL studies mainly focused on cognitive and affective outcomes and there is lack of review on conative outcomes of PBL instruction. Nevertheless, in these analyses, PBL students seemed to have gained better performance than those students with traditional training in knowledge principles and application, problem solving, and 
self-directed learning, whereas traditional students' performance in basic knowledge were better than PBL students.

\section{Method}

This paper examined the dissertations on PBL in the National Thesis Database of CoHE in Turkey. For this purpose, the master's and doctorate dissertations were searched by using "problem-based learning" as a keyword with no time restrictions. A total of 129 dissertations (82 master's, 47 doctorate) were found (as of December 2016), 20 (12 master's, 8 doctorate) of which were not accessible due to restrictions requested by the authors themselves. In line with pre-determined criteria of inclusion, out of the remaining 109 dissertations (70 master's, 39 doctorate), 8 dissertations (6 master's, 2 doctorate) that failed to provide information for the majority of the selected analysis criteria were eliminated by the author and raters unanimously. In the end, 101 dissertations (63 master's, 38 doctorate), were included in the study (the list of dissertations is in Appendix A). They were all downloaded from the database and undergone rigorous content analysis.

Content analysis was chosen as a qualitative method to investigate the research trends in research. Content analysis is defined by Krippendorff [31] as "a research technique for making replicable and valid inferences from texts (or other meaningful matter) to the contexts of their use" (p. 18). Additionally, Cohen, Manion and Morrison [32] define it as "the process of summarizing and reporting written data - the main contents of data and their messages" (p. 475). They also add that "it defines a strict and systematic set of procedures for the rigorous analysis, examination and verification of the contents of written data." As Krippendorff states it, content analysis is learnable and divorceable from the personal authority of the researcher and it "provides new insights, increases a researcher's understanding of particular phenomena, or informs practical actions" (p. 18). Therefore, the author preferred this scientific tool to investigate research trends in dissertations in order to inform practitioners and the faculty about PBL's practical actions and considerations.

\subsection{Data coding and analysis}

This study used 101 dissertations derived from the Council of Higher Education National Thesis Database in Turkey that were completed from 2002 to 2015 to examine the research trends in the PBL field. Throughout the process of content analysis, three colleagues with doctorate degrees in educational sciences helped the author in reviewing the dissertations and doing the analyses. The agreement among the raters was calculated as 90.2 .

As one of the major purposes of this study, a dissertation classification form (DCF) was developed by the author and assisting colleagues to classify the categories to help identify the research trends. This form was inspired from a previously developed "paper classification form" of Sözbilir and Kutu [33]. After examined by colleagues and experts, the form was implemented on randomly selected 15 dissertations for reliability. The results of this initial trial were discussed to alleviate any disagreements on the items. According to discussions and negotiations, the form was revised again and its final version (see Appendix B) was agreed upon to be used for comprehensive content analysis.

In line with the second research objective, the results obtained in these dissertations were also examined and reported separately with regards to cognitive, affective and conative domains.

For the analysis purposes, by means of the dissertation classification form, all data were recorded on an electronic database and later transferred to SPSS 20. Frequencies and percentages were calculated for each category. These data were later commented and discussed.

\section{Findings}

\subsection{Research Question 1}

Among the 101 studies examined in this research, 63 were master's studies and 38 were doctoral studies (Table 1). The studies on PBL reached their peak through the period from 2007 to 2013 (a total of 83 theses), with the highest number of research completed in the years of 2009 and 2013. By examining the findings, it may be plausible to infer that the number of research decreased after 2013; however 10 of 20 dissertations $(2014=5,2015=5)$ found in the database but not accessed due to authors' restrictions account for the gap.

Table 1. Frequencies of Study Types from 2002-2015

\begin{tabular}{|c|c|c|c|}
\hline \multirow{2}{*}{ Year } & \multicolumn{2}{|c|}{ Type of Study } & \multirow{2}{*}{ Grand Total } \\
\cline { 2 - 3 } & Master's & PhD & 1 \\
\hline 2002 & & 1 & 2 \\
\hline 2004 & 1 & 1 & 2 \\
\hline 2005 & & 2 & 4 \\
\hline 2006 & 2 & 2 & 11 \\
\hline 2007 & 8 & 3 & 12 \\
\hline 2008 & 8 & 4 & 13 \\
\hline 2009 & 9 & 4 & 11 \\
\hline 2010 & 9 & 2 & 12 \\
\hline 2011 & 9 & 3 & 11 \\
\hline 2012 & 4 & 7 & 13 \\
\hline 2013 & 8 & 5 & 5 \\
\hline 2014 & 3 & 2 & 4 \\
\hline 2015 & 2 & 2 & 101 \\
\hline Grand Total & 63 & 38 & \\
\hline
\end{tabular}


Analysis show that PBL research was most frequently utilized in the learning domain of science ( $86 \%$ ), followed by social studies domain $(10 \%)$, whereas there were only 2 studies in the domain of arts and 3 studies in the domain of language arts (Table 2).

The findings on research method revealed that quantitative methodology was more prevalent among the dissertations. $51.52 \%$ of the studies used quantitative research methodology, whereas $48.5 \%$ utilized quantitative and qualitative research methods (Table 3 ).

It was found that researchers favored experimental design $(90.1 \%)$ more than the others (Table 4).

The analysis on research domain focused in studies revealed some interesting facts. The most frequently focused research domain was cognition and affect $(56.4 \%)$, followed by cognition only $(27.7 \%)$ (Table 5$)$.

Table 2. Frequencies of Learning Domains from 2002-2015

\begin{tabular}{|c|c|c|c|c|}
\hline \multirow{2}{*}{ Year } & \multicolumn{4}{|c|}{ Learning Domain } \\
\cline { 2 - 5 } & Arts & $\begin{array}{c}\text { Language } \\
\text { Arts }\end{array}$ & Science & Social Studies \\
\hline 2002 & & & 1 & 1 \\
\hline 2004 & & & 1 & 1 \\
\hline 2005 & & 1 & 3 & 1 \\
\hline 2006 & & & 11 & \\
\hline 2007 & & & 9 & 2 \\
\hline 2008 & 1 & & 11 & 2 \\
\hline 2009 & & & 9 & 1 \\
\hline 2010 & & & 10 & \\
\hline 2011 & 1 & 1 & 11 & 2 \\
\hline 2012 & & 1 & 5 & \\
\hline 2013 & & & 4 & \\
\hline 2014 & & & 86 & 10 \\
\hline 2015 & & & & \\
\hline $\begin{array}{c}\text { Grand } \\
\text { Total }\end{array}$ & 2 & 3 & & \\
\hline
\end{tabular}

Table 3. Frequencies of Research Methods Utilized from 2002-2015

\begin{tabular}{|c|c|c|}
\hline \multirow{2}{*}{ Year } & \multicolumn{2}{|c|}{ Research Method } \\
\cline { 2 - 3 } & Quantitative & Quantitative and Qualitative \\
\hline 2002 & 1 & 1 \\
\hline 2004 & 1 & \\
\hline 2005 & 2 & 3 \\
\hline 2006 & 1 & 4 \\
\hline 2007 & 7 & 5 \\
\hline 2008 & 7 & 6 \\
\hline 2009 & 7 & 5 \\
\hline 2010 & 6 & 5 \\
\hline 2011 & 7 & 8 \\
\hline 2012 & 3 & 5 \\
\hline 2013 & 8 & 5 \\
\hline 2014 & & 2 \\
\hline 2015 & 2 & 49 \\
\hline Grand Total & 52 & \\
\hline
\end{tabular}

Table 4. Frequencies of Research Designs Utilized in Dissertations from 2002-2015

\begin{tabular}{|c|c|c|c|c|}
\hline \multirow{2}{*}{ Year } & \multicolumn{3}{|c|}{ Research Method } & \\
\hline & $\begin{array}{c}\text { Action } \\
\text { Research }\end{array}$ & Experimental & Survey & Case Study \\
\hline 2002 & & 1 & & \\
\hline 2004 & & 2 & & \\
\hline 2005 & & 1 & 1 & \\
\hline 2006 & & 4 & & \\
\hline 2007 & & 11 & & \\
\hline 2008 & 1 & 10 & 1 & \\
\hline 2009 & & 11 & 2 & \\
\hline 2010 & 1 & 10 & & \\
\hline 2011 & & 12 & & \\
\hline 2012 & 1 & 8 & 1 & 1 \\
\hline 2013 & & 13 & & \\
\hline 2014 & & 5 & & \\
\hline 2015 & & 3 & 1 & \\
\hline Grand Total & 3 & 91 & 6 & 1 \\
\hline
\end{tabular}


Table 5. Frequencies of Research Domains Focused in Research from 2002-2015

\begin{tabular}{|c|c|c|c|c|c|c|}
\hline \multirow[b]{2}{*}{ Year } & \multicolumn{6}{|c|}{ Research Domain } \\
\hline & Affect & Cognition & Cognition and Affect & $\begin{array}{c}\text { Cognition and } \\
\text { Conation }\end{array}$ & $\begin{array}{l}\text { Affect and } \\
\text { Conation }\end{array}$ & $\begin{array}{c}\text { Cognition, Affect and } \\
\text { Conation }\end{array}$ \\
\hline 2002 & & & 1 & & & \\
\hline 2004 & & 1 & & & & 1 \\
\hline 2005 & 1 & & 1 & & & \\
\hline 2006 & & & 3 & & & 1 \\
\hline 2007 & & 5 & 4 & 1 & & 1 \\
\hline 2008 & 1 & 2 & 9 & & & \\
\hline 2009 & 1 & 3 & 7 & & & 2 \\
\hline 2010 & & 2 & 8 & & & 1 \\
\hline 2011 & 1 & 6 & 5 & & & \\
\hline 2012 & & & 9 & & & 2 \\
\hline 2013 & & 5 & 7 & 1 & & \\
\hline 2014 & & 3 & 1 & & & 1 \\
\hline 2015 & & 1 & 2 & & 1 & \\
\hline Grand Total & 4 & 28 & 57 & 2 & 1 & 9 \\
\hline
\end{tabular}

The findings showed that the most frequently used subject group in the experimental studies were elementary education students (42.6\%), followed by teacher education students (31.7\%) (Table 6).

Table 6. Frequencies of Subject Group in Research from 2002-2015

\begin{tabular}{|c|c|c|c|c|}
\hline \multirow{2}{*}{ Year } & \multicolumn{3}{|c|}{ Subject Group } \\
\cline { 2 - 5 } & Elementary Education & Secondary Education & Higher Education & Teacher Education \\
\hline 2002 & 1 & & 1 & 1 \\
\hline 2004 & & 1 & 1 & 1 \\
\hline 2005 & 2 & 1 & 1 & 3 \\
\hline 2006 & 5 & 2 & 1 & 4 \\
\hline 2007 & 3 & 4 & 2 & 5 \\
\hline 2008 & 5 & 1 & 1 & 4 \\
\hline 2009 & 5 & 1 & 1 & 4 \\
\hline 2010 & 7 & 1 & 2 & 5 \\
\hline 2011 & 4 & 1 & 1 & 3 \\
\hline 2012 & 7 & 1 & 11 & 1 \\
\hline 2013 & 2 & 2 & & 1 \\
\hline 2014 & 2 & 15 & & 32 \\
\hline 2015 & 43 & & & \\
\hline Grand Total & & & & \\
\hline
\end{tabular}

Considering group sizes, the studies on PBL preferred to have group sizes of $41-80(60.4 \%)$, whereas the percentages of studies which used group sizes of 1-40, 81-120, and 120 and above were $17.8 \%, 11.9 \%$ and 12.5\%, respectively (see Table 7 ). 
What Does Research Tell Us about Trends in Dissertations on PBL?

Table 7. Frequencies of Group Sizes Utilized in Research from 2002-2015

\begin{tabular}{|c|c|c|c|c|}
\hline \multirow{2}{*}{ Year } & \multicolumn{4}{|c|}{ Group Size } \\
\hline & $1-40$ & $41-80$ & $81-120$ & 121 and above \\
\hline 2002 & & 1 & & \\
\hline 2004 & & 2 & & \\
\hline 2005 & & 1 & & 1 \\
\hline 2006 & & 3 & 1 & \\
\hline 2007 & 2 & 4 & 2 & 3 \\
\hline 2008 & 4 & 5 & 2 & 1 \\
\hline 2009 & 1 & 9 & 1 & 2 \\
\hline 2010 & 1 & 10 & & \\
\hline 2011 & 1 & 9 & 2 & \\
\hline 2012 & 3 & 5 & 1 & 2 \\
\hline 2013 & 4 & 6 & 2 & 1 \\
\hline 2014 & 1 & 4 & & \\
\hline 2015 & 1 & 2 & 1 & \\
\hline Grand Total & 18 & 61 & 12 & 10 \\
\hline
\end{tabular}

Taking the length of treatments into account, the treatments on PBL research lasted mostly four weeks (17.8\%), five weeks $(11.9 \%)$ and six weeks (16.8\%) (Table 8).

Table 8. Frequencies of Length of Treatments in Research from 2002-2015

\begin{tabular}{|c|c|c|c|c|c|c|c|c|c|c|c|c|c|c|c|}
\hline \multirow[b]{2}{*}{ Year } & \multicolumn{15}{|c|}{ Length of treatment } \\
\hline & $\begin{array}{c}7 \\
\text { hours }\end{array}$ & $\begin{array}{c}2 \\
\text { weeks }\end{array}$ & $\begin{array}{c}3 \\
\text { weeks }\end{array}$ & $\begin{array}{c}4 \\
\text { weeks }\end{array}$ & $\begin{array}{c}5 \\
\text { weeks }\end{array}$ & $\begin{array}{c}6 \\
\text { weeks }\end{array}$ & $\begin{array}{c}7 \\
\text { weeks }\end{array}$ & $\begin{array}{c}8 \\
\text { weeks }\end{array}$ & $\begin{array}{c}9 \\
\text { weeks }\end{array}$ & $\begin{array}{c}10 \\
\text { weeks }\end{array}$ & $\begin{array}{c}12 \\
\text { weeks }\end{array}$ & $\begin{array}{c}14 \\
\text { weeks }\end{array}$ & $\begin{array}{c}15 \\
\text { weeks }\end{array}$ & $\begin{array}{c}19 \\
\text { weeks }\end{array}$ & Non-Specified \\
\hline 2002 & & & & & & & 1 & & & & & & & & \\
\hline 2004 & & & & & & 1 & & & & & 1 & & & & \\
\hline 2005 & & & 1 & & & & & & & & & & & & 1 \\
\hline 2006 & & & & 1 & & 2 & & & & & & 1 & & & \\
\hline 2007 & & 1 & & 3 & 3 & 2 & & & & 1 & & & & & 1 \\
\hline 2008 & & & & 4 & & 2 & 1 & & 1 & & & 3 & & & 1 \\
\hline 2009 & & & 1 & 3 & 1 & 2 & 1 & & 1 & 1 & 2 & & & & 1 \\
\hline 2010 & 1 & & 1 & & 2 & 4 & & 2 & 1 & & & & & & \\
\hline 2011 & & & 2 & 4 & 1 & 1 & 1 & 1 & 1 & & & 1 & & & \\
\hline 2012 & & & & 2 & 1 & 2 & 1 & 1 & 1 & & & 2 & & & 1 \\
\hline 2013 & & & 1 & 1 & 3 & & 1 & 3 & & 1 & 2 & & 1 & & \\
\hline 2014 & & & & & 1 & 1 & & 1 & 1 & & & & & 1 & \\
\hline 2015 & & & 2 & & & & & 1 & & & & & 1 & & \\
\hline Grand Total & 1 & 1 & 8 & 18 & 12 & 17 & 6 & 9 & 6 & 3 & 5 & 7 & 2 & 1 & 5 \\
\hline
\end{tabular}

The findings of the content analysis showed that there were 37 different types and in total 320 instruments used to collect data for research purposes. It is quite obvious that majority of the studies used achievement tests (30.9\%) and attitude scales $(18.1 \%)$ as instruments of measurement (see Table 9). The instruments categorized under the title "attitude scale" were the ones used to assess students' dispositions towards the course subject in which PBL was implemented (attitude towards chemistry, math, science and technology, etc.). 
Table 9. Frequencies of Measurement Instruments Used in Research from 2002-2015

\begin{tabular}{|c|c|c|c|}
\hline No. & Type of Measures & $(f)$ & $\%$ \\
\hline 1 & Achievement test (Including summative, formative, performance, and application tests) & 99 & 30,9 \\
\hline 2 & Attitude Scale & 58 & 18,1 \\
\hline 3 & Interview Forms & 35 & 10,9 \\
\hline 4 & Scientific Process Skills Test & 17 & 5,3 \\
\hline 5 & Instruments Specific to PBL (e.g. attitudes towards PBL, group processes and assessment activities in PBL, efficacy) & 13 & 4,1 \\
\hline 6 & Problem Solving Tests (e.g. Heppner's Problem Solving Inventory) & 12 & 3,8 \\
\hline 7 & Creative Thinking Tests (e.g. Torrance Test of Creativity) & 11 & 3,4 \\
\hline 8 & Observation Forms & 11 & 3,4 \\
\hline 9 & Self-peer and performance Assessment Forms & 11 & 3,4 \\
\hline 10 & Scales on Motivation (e.g. Motivational Styles Questionnaire, Motivational Strategies in Learning Scale) & 8 & 2,5 \\
\hline 11 & Critical Thinking Scales (e.g. California Critical Thinking Aptitude Scale) & 6 & 1,9 \\
\hline 12 & Student Survey (questions on individual studies, group studies, instructors, PBL) & 6 & 1,9 \\
\hline 13 & Scale on Self-regulated Learning & 3 & 0,9 \\
\hline 14 & Self-Efficacy Scale & 3 & 0,9 \\
\hline 15 & Academic Risk Taking Scale & 2 & 0,6 \\
\hline 16 & Learning Approach Scale & 2 & 0,6 \\
\hline 17 & Logical Thinking Test & 2 & 0,6 \\
\hline 18 & Self-directed Learning Readiness Scale & 2 & 0,6 \\
\hline 19 & Academic Self-Concept & 1 & 0,3 \\
\hline 20 & Affective Tendencies Scale & 1 & 0,3 \\
\hline 21 & Behavior Scale & 1 & 0,3 \\
\hline 22 & Competence Perception Scale & 1 & 0,3 \\
\hline 23 & Concept Inventory & 1 & 0,3 \\
\hline 24 & Constructivist Learning Environment Survey & 1 & 0,3 \\
\hline 25 & Inquiry Learning Skills Perception Scale & 1 & 0,3 \\
\hline 26 & Mathematical Thinking Scale & 1 & 0,3 \\
\hline 27 & Pedagogical Content Knowledge Concept Maps & 1 & 0,3 \\
\hline 28 & Scale on Anxiety in Math & 1 & 0,3 \\
\hline 29 & Scale on Clinical Reasoning & 1 & 0,3 \\
\hline 30 & Scale on Learned Helplessness in Math & 1 & 0,3 \\
\hline 31 & Scale on Locus of Control & 1 & 0,3 \\
\hline 32 & Scale on Metacognition & 1 & 0,3 \\
\hline 33 & Science Reasoning Aptitude Test & 1 & 0,3 \\
\hline 34 & Science Teaching Orientation Test & 1 & 0,3 \\
\hline 35 & Scientific Structure Creativity Model & 1 & 0,3 \\
\hline 36 & Student Portfolios & 1 & 0,3 \\
\hline 37 & Student Understanding Knowledge Test & 1 & 0,3 \\
\hline \multicolumn{2}{|r|}{ Grand Total } & 320 & 100 \\
\hline
\end{tabular}

The cross-reference of the findings depicted in Tables 1-9 revealed some more facts and trends about dissertations. Taking the subject groups into account, the majority of master's research $(\mathrm{N}=34,53.1 \%)$ was conducted with students at elementary education level, whereas the doctoral studies were carried on with teacher candidates $(\mathrm{N}=21$, $56.8 \%$ ). Science as the predominant learning domain was preferred in 37 of 43 master's studies (86\%) and in 27 of 32 doctoral research $(84.4 \%)$. The most popular subjects grouped under the science category were math $(\mathrm{N}=21)$, science teaching $(\mathrm{N}=15)$, chemistry $(\mathrm{N}=14)$ and science and technology $(\mathrm{N}=12)$. In majority, studies conducted in elementary education chose math $(\mathrm{N}=12)$, science and technology $(\mathrm{N}=12)$ and science teaching $(\mathrm{N}=9)$ as the 
learning domain, whereas studies completed in teacher education chose physics $(\mathrm{N}=7)$ and chemistry $(\mathrm{N}=7)$. Considering the length of treatments, 10 of the 18 treatments that lasted $10+$ weeks were completed in teacher education, four of the remaining research was held in higher education institutions. As stated before the treatments in master's research mostly lasted 4-6 weeks (in 25 out of 43 studies).

The qualitative findings derived from interviews and observations were too fragmented to include in the present study, hence should be reported in detail somewhere else. However, a surface analysis of those qualitative findings indicated that PBL was reported to increase students' engagement, taking responsibility of their own learning, cooperation and interaction among group members and their self-efficacy in various subjects. The reports also showed that students learned more by doing or working on real life problems, they used higher-order thinking skills more frequently, they searched and shared more sources, hence their research skills developed substantially. On the other hand; difficulty in having access to information, noise in the classroom, confusion in the beginning, having difficulty in adapting to active participation instead of passive learning were some of the challenges noted.

\subsection{Research Question 2}

The findings of content analysis showed that PBL students did better in achievement tests than their conventional counterparts, except for a few studies $(\mathrm{N}=12)$, where no difference was observed between two groups of students. It is important to note that seven of those non-significant findings were obtained in studies at elementary education level, which lasted 3-5 weeks and focused on students' achievements only in one unit (e.g. human and environment, algebraic expositions and equations, concept of area and perimeter). On the other hand, in other research which also lasted 3-5 weeks $(\mathrm{N}=31)$, students in PBL classes showed significant progress in their achievements. Nevertheless, the findings of the present study regarding cognitive outcomes of PBL instruction revealed that PBL students were superior to traditional students both in factual and conceptual knowledge and specifically in skills of knowledge application. These findings seem to be in line with those of previous meta-analyses and reviews [7, 8, 12, 13], where PBL students were found to be doing better or equally well as their conventional counterparts.

Regarding the findings on attitudes on course subjects (e.g. chemistry, biology, etc.), in 35 studies out of 58 (60.3\%), there was positive influence of PBL instruction on student attitudes, whereas in the remaining studies no significant difference was observed. Among those 23 studies with PBL treatment's no significant influence on attitudes, 16 were master's and 7 were doctoral research; 13 studies were conducted at elementary education level, and science teaching $(\mathrm{N}=7)$ and math $(\mathrm{N}=7)$ were the learning domains. Overall, as reported in prior reviews on PBL instruction [4,
5], PBL students' attitudes and dispositions towards learning after PBL treatment and student and faculty satisfaction with the instruction were found positive. In those studies examining students' dispositions towards the PBL itself $(\mathrm{N}=13, \mathrm{PhD}=7$ and Master's $=6)$, student reports were highly favorable and positive.

The findings regarding other measures revealed mixed results. Considering the more frequently utilized measures, the PBL instruction was found to have significant effect on scientific process skills in 12 out of 17 studies $(70.6 \%)$, on creative thinking skills in 6 out of 11 studies $(54.5 \%)$, and on problem solving skills in 8 out of 12 studies (66.7\%).

The only studies that investigated conative outcomes of PBL instruction focused on such elements like self-direction/self-regulation, motivational styles and strategies, locus of control, and learning approaches. In 5 out of 8 studies focusing on motivational elements and in two studies examining learning approaches in PBL contexts, the findings demonstrated that PBL instruction had significant influence. While the studies investigating PBL's influence on self-directed learning readiness (one 4-week and one 15-week treatment) showed significant differences, the studies on PBL's effect on students' self-regulatory skills and locus of control reported mixed results. Students' self-regulation levels and their locus of control in PBL contexts were found to be similar to those of students in traditional teaching and learning settings after treatment periods of 12, 14 and 15 weeks; however in a research which lasted 19 weeks at elementary education level, significant positive gains were recorded on students' self-regulated learning scores. The inconclusive and inconsistent results did not provide enough evidence on PBL's positive influence on such elements. Having no concordance with the results of studies by Leary [10] and Loyens, Magda and Rikers [11], these findings confirm the necessity to have more research to get a better picture of PBL's influence on conative elements like self-direction or self-regulation.

\section{Discussion}

This study aimed to investigate the research trends in studies of PBL from 2002 to 2015 in Turkey. The results of the findings are discussed and commented below.

The content analysis of master's and doctoral dissertations showed that the number of studies on PBL was the highest during the period of 2007-2013. However, this increase in the number of dissertations is considered unexceptional since constructivist approaches were introduced into Turkish education system starting in 2005-2006 Academic Year.

Considering the analyses results of categories under focus, this study indicated that; science was the most favorable learning domain (see Table 2), quantitative method was slightly more utilized as compared to qualitative and quantitative (mixed) methodology (see Table 3), experimental was the dominant design in the dissertations 
(see Table 4), cognition and affect followed by cognition only were the mostly utilized research domains (see Table 5), subject groups were predominantly at elementary education level and secondly from teacher education (see Table 6), studies preferred to have the subject group size of 41-80 (see Table 7), the treatments on PBL research lasted mostly four and six weeks (see Table 8), and finally majority of the studies used achievement tests and attitude scales (see Table 9) as instruments of measurement.

These findings with regard to the first research question revealed evidence on several research trends. First, studies generally focused on PBL's effect on cognition and affect, hence they preferred to use achievement tests and attitude scales of various sorts. Second, there was an increase in the utilization of both quantitative and qualitative methods together, although it was slightly lower than quantitative method only. Third, studies at elementary education and teacher education were on the rise. Fourth, it is obvious that science was and potentially will continue being the dominant learning domain in PBL research. Finally, the researchers' preferences for length of treatment in majority ranged from 3 to 9 weeks due to curricular and time constraints.

The findings regarding PBL's influence on cognitive and affective outcomes seemed to be in concordance with the findings obtained in previous meta-analyses and reviews. Supporting the reports of Albanese and Mitchell [4], Dochy et al. [7], Gijbels et al. [8] and Üstün [13], in the present study there is evidence on PBL's significant positive effect on knowledge application, however contrary to previous reviews $[5,6,9,12]$, PBL's meaningful influence on basic knowledge is observed as well. Also, similar to the findings in other reviews $[13,12]$, this study revealed some affective outcomes like positive attitudes and views towards learning of subjects and specifically on the implementation of PBL.

In comparison with previous meta-analyses and reviews, it is clear that PBL research in Turkish dissertations was mainly concerned about cognitive outcomes and secondly affective outcomes. There were just a few studies which focused on conative elements of learning like self-direction, self-regulation, locus of control, and motivational strategies in learning. Leary [10] pointed to the same fact and suggested that more studies should be done in order to get a better picture of PBL's influence on SDL and SRL. The results in the present study regarding the elements of this domain were found inconclusive. The same mixed results on whether PBL fosters self-direction or self-regulation were also reviewed in the study of Loyens, Magda and Rikers [11]. Erdogan and Senemoglu [34] addressed to this issue in their research and stated that different study results on PBL's effect on conative elements such as self-direction/self-regulation could be explained by students already being equipped with such skills and the short period of application reserved to see the changes PBL would have on them. Similarly, in their study investigating students' progress on self-regulation through undergraduate levels of 1-4, Van der Hurk, Wolfhagen, Dolmans and Van der
Vleuten [35] found that real development occurred only in the $3 \mathrm{rd}$ and 4 th grades. It is viable to say that a better and healthier observation of self-directed/self-regulated skills development or the improvement of other conative elements could be made in a study that would last longer than a few months or a year.

The qualitative results of the dissertations revealed overall positive attitudes towards PBL instruction on part of both learners and teachers. In their reviews, Albanese and Mitchell [4] noted the same satisfaction of faculty and students with PBL instructional method. Certainly, an increase in qualitative assessments like interviews could provide faculty and teachers with valuable aspects of PBL use.

So far, the dissertations on PBL showed promising results. Because, instead of passive learning, in PBL students participate in cooperative learning groups where they work on real life problems, hence they have the chance to search for more information, access different sources, see the actual practical results of theoretical constructs and eventually take the responsibility of their own learning. However, more studies are required before conclusions are drawn about the effectiveness and usefulness of PBL in a variety of disciplines and levels. As in the studies found in literature, the real influence of PBL can be seen in activities based on application and in real life problems encountered during occupational experiences $[36,15,37]$. Therefore, studies on long-term effects of PBL use, which would also cover after school periods, could provide the faculty and teachers with better picture of PBL's real power.

Considering the methodologies used in the dissertations, it is important to note that except for a few medical schools, in none of the studies PBL was the common methodology followed and implemented through all levels and courses. In other words, PBL was implemented and the results were analyzed as part of a research, in which PBL as a constructive methodology was new to both instructors and teachers. Further, a few studies undertaken about Turkish education system has shown that neither teachers nor students were ready enough to accept or adopt the new constructivist approaches, both at theoretical and application level. Teacher training programs and in-service courses were seen insufficient; crowded classes, having difficulty at accessing sources, lack of infrastructure such as laboratories added up the problem; the teachers and students tended to continue using traditional teaching and assessment approaches more frequently [38, 39]. Additionally; Gür, Dilci and Arseven [40] reported that prospective (pre-service) teachers found themselves adequate in terms of theoretical knowledge, but lacked practical knowledge. Student teachers believed that deficiency originated from lack of education including enough training on constructivist applications. Aygören [41] suggested that even school administrators were in need of in-service training on constructivism and constructivist learning environments.

It was found that specific care was given to put the 
instructional principles of PBL methodology into action. The courses were designed to begin with the introduction of an ill-structured problem, where teachers acted as facilitators and learners actively constructed knowledge by defining learning goals, seeking information to build upon prior knowledge, reflecting on the learning process, and participating actively in cooperative/ collaborative learning groups [16, 17, 18]. However, under the condition of insufficient infrastructural support (e.g. no tutorial rooms, limited access to information in and out of classes through the Internet, small crowded classes, etc.) and tutors not assigned to tutorial groups especially at elementary and secondary education levels challenged the instructors to develop their own version of PBL. For example, in one of the dissertations, in the absence of specific tutors to each cooperative group in a large class, the researcher described the instructor taking the role of a "floating tutor" [42, p. 40-41]. Barrows [19] also exemplified different versions of PBL methodologies that might vary according to different conditions, settings, learner groups, etc.

Regarding the findings of the present research and those in literature confirm the fact that PBL could be used as an instructional methodology in all disciplines and subject areas, through all levels (from elementary to higher education) as long as the core principles are practiced. However, it is not plausible to expect immediate results from a PBL implementation in the beginning. Also, it is also not viable to expect sudden changes in student roles. Students may need more time and experience as they have been taught passively in controlled and well-structured learning environments. It is deemed important that for the successful application of methods like PBL, infrastructure needs should be met and necessary changes must be incorporated into the curriculum, especially to content and timing. The undergraduate and in-service training of teachers as practitioners on constructivist teaching and learning methodologies including PBL should be granted priority. Finally, it is worth remembering that it is the responsibility of practitioners to ensure the implementation of PBL according to its principles, to provide assistance to students in their transition to more active learning, cooperation and taking responsibility of their own learning.

\section{Conclusions}

The present study examined the research trends in studies of problem-based learning from 2002 to 2015 in Turkey. For this purpose, 101 master's and doctoral dissertations underwent rigorous content analysis. In short, this study suggested some research trends in PBL dissertations through years. Besides these major considerations, this present research drew attention to analysis of the findings with regard to cognitive, affective, and conative outcomes.

The research has limitations though. First, the current study focused only on PBL dissertations completed between 2002 and 2015 and published in the dissertation database of CoHE in Turkey. Second, for analysis purposes, the study reviewed only the learning domains, research methods, research designs, research domains, subject groups, group sizes, length of treatments, and data collection instruments in these dissertations and analyzed the findings with regards to cognition, affect and conation. Third, the dissertations not accessed due to authors' restrictions and those providing not sufficient data for analysis were kept out of scope.

The findings of this analysis indicated that constructivist learning approaches such as PBL could be used successfully in other disciplines apart from medical education and could be utilized in different levels from primary to higher education. However, a comparative analysis of these findings in Turkey with those results of PBL studies in other countries or comparing the present findings with the results of studies investigating other constructivist methodologies such as project-based learning, case-based learning etc. would assist researchers in their prospective studies and at the same time create a better picture of strengths and challenges of using constructivist teaching and learning applications.

In conclusion; PBL as educational practice continues to have large impacts on all levels of education and across different disciplines. While the results of studies examining the effects of PBL seem to be conclusive regarding students' problem-solving abilities, attitudes and predispositions towards learning, and clinical or occupational skills in application, much more needs to be known about PBL's influence on the acquisition of basic knowledge and some conative elements like self-direction/self-regulation and locus of control. 


\section{Appendix A}

\section{List of Dissertations Used in the Analyses}

\begin{tabular}{|c|c|c|c|c|}
\hline No. & Author & Year & Research Topic & Type of Study \\
\hline 1 & HANDAN DEVECİ & 2002 & $\begin{array}{l}\text { The effect of problem based learning to attitudes, } \\
\text { success and retention in social studies }\end{array}$ & $\mathrm{PhD}$ \\
\hline 2 & METIN AÇIKYILDIZ & 2004 & $\begin{array}{c}\text { Investigation of effectiveness of problem-based learning at physical } \\
\text { chemistry laboratory experiments }\end{array}$ & Master's \\
\hline 3 & BÜLENT AKSOY & 2004 & Problem based learning approach in geography teaching & $\mathrm{PhD}$ \\
\hline 4 & SELAMİ OK & 2005 & $\begin{array}{c}\text { The analysis of an English preparatory program based on the needs } \\
\text { assessment of problem-based learning and regular groups in a foreign } \\
\text { language-medium institution }\end{array}$ & $\mathrm{PhD}$ \\
\hline 5 & SELÇUK ÖZDEMIR & 2005 & $\begin{array}{c}\text { The effects of individual and collaborative problem-based learning using an } \\
\text { online synchronized learning tool on critical thinking abilities, academic } \\
\text { achievements, and attitudes toward internet use }\end{array}$ & $\mathrm{PhD}$ \\
\hline 6 & BERNA CANTÜRK GÜNHAN & 2006 & $\begin{array}{l}\text { An investigation on applicability of problem based learning in the } \\
\text { mathematics lesson at the second stage in the elementary education }\end{array}$ & $\mathrm{PhD}$ \\
\hline 7 & EDA ERDEM & 2006 & $\begin{array}{l}\text { The effect of problem based learning on learning outcomes, problem solving } \\
\text { skills and self-efficiency beliefs of prospective teachers }\end{array}$ & $\mathrm{PhD}$ \\
\hline 8 & GÜLSEMIN USLU & 2006 & $\begin{array}{l}\text { The Effect of problem based learning to attitudes, success and level of } \\
\text { performance of the students in secondary school mathematics lesson }\end{array}$ & Master's \\
\hline 9 & KORAY TAVUKCU & 2006 & $\begin{array}{l}\text { The effects on the learning outcomes of problem based learning } \\
\text { in science instruction }\end{array}$ & Master's \\
\hline 10 & GÜLSÜM ARAZ & 2007 & $\begin{array}{l}\text { The effect of problem-based learning on the elementary school students } \\
\text { achievement in genetics }\end{array}$ & Master's \\
\hline 11 & DERYA ÇINAR & 2007 & $\begin{array}{c}\text { The effects of the problem based learning approach on the higher level } \\
\text { thinking skills and levels of academic risk taking } \\
\text { in primary science education }\end{array}$ & Master's \\
\hline 12 & ÖZGE ÖZYALÇIN OSKAY & 2007 & $\begin{array}{c}\text { Technology assisted problem-based learning applications } \\
\text { in chemistry education }\end{array}$ & $\mathrm{PhD}$ \\
\hline 13 & RAMIS BAYRAK & 2007 & Teaching solids by problem based learning & $\mathrm{PhD}$ \\
\hline 14 & ERDAL TATAR & 2007 & $\begin{array}{c}\text { Effect of problem based learning approach on understanding of the first law } \\
\text { of thermodynamics }\end{array}$ & $\mathrm{PhD}$ \\
\hline 15 & EROL GÜRPINAR & 2007 & $\begin{array}{c}\text { Instruction technologies in medical education: integration of e-learning and } \\
\text { problem based learning }\end{array}$ & Master's \\
\hline 16 & NESLIHAN SIFOĞLU & 2007 & $\begin{array}{l}\text { The Effects of constructivism and problem-based learning on students' } \\
\text { success in the teaching the topic heritage' at the 8th grade }\end{array}$ & Master's \\
\hline 17 & MÜGE YURD & 2007 & $\begin{array}{c}\text { The effect of know-want-sample-learn strategy, which is developed by using } \\
\text { problem based learning and know-want-learn strategy, towards the } 5 \text { th grade } \\
\text { students' attitudes in science and technology lesson and towards to remove } \\
\text { their misconceptions }\end{array}$ & Master's \\
\hline 18 & KEMAL ÖZGEN & 2007 & $\begin{array}{l}\text { The effects of problem based learning approach on learning products in } \\
\text { mathematics lesson }\end{array}$ & Master's \\
\hline 19 & TUNCAY ÇAKIR & 2007 & $\begin{array}{l}\text { The effect of problem-based learning method on students' achievement, } \\
\text { retention and attitude in teaching the circle subjects that are in math course at } \\
\text { seventh grade in elementary school }\end{array}$ & Master's \\
\hline 20 & ERHAN GÜNEŞ & 2007 & $\begin{array}{l}\text { The effects of different types of feedback strategies and attitudes of students } \\
\text { towards internet on learning in web-mediated problem-based learning }\end{array}$ & Master's \\
\hline 21 & SELCEN İŞERİ GÖKMEN & 2008 & $\begin{array}{l}\text { Effects of problem based learning on students' environmental attitude through } \\
\text { local vs. non local environmental problems }\end{array}$ & Master's \\
\hline 22 & MERAL PAKYÜREK KARAÖZ & 2008 & $\begin{array}{l}\text { The effect of teaching the unit of 'power and motion' in primary school } \\
\text { science course using the problem based learning approach on students science } \\
\text { process skills, success and attitude }\end{array}$ & Master's \\
\hline 23 & AHMET KUMAŞ & 2008 & $\begin{array}{l}\text { An assessment and implementation of problem based learning in cooperative } \\
\text { learning groups in the unit of motion on the earth }\end{array}$ & Master's \\
\hline 24 & SITKI AKIN & 2008 & $\begin{array}{l}\text { Teaching environmental problems caused by stubble fires, ozone layer } \\
\text { depletion and vehicles through problem-based learning }\end{array}$ & Master's \\
\hline 25 & ZEYNEP OYA ÜNAL & 2008 & $\begin{array}{l}\text { The effect of problem based learning on competence perception } \\
\text { in piano and its teaching }\end{array}$ & $\mathrm{PhD}$ \\
\hline 26 & ESRA KANLI & 2008 & $\begin{array}{c}\text { The effect of problem based learning in science \& technology instruction on } \\
\text { gifted and normal students' achievement, } \\
\text { creative thinking and motivation levels }\end{array}$ & Master's \\
\hline 27 & MURAT KOÇAK & 2008 & $\begin{array}{l}\text { The effect of problem based learning to attitudes, success and level of } \\
\text { permanence of the students in secondary school geography lessons }\end{array}$ & Master's \\
\hline
\end{tabular}




\begin{tabular}{|c|c|c|c|c|}
\hline 28 & SERKAN ŞENDAĞ & 2008 & $\begin{array}{l}\text { The effect of online problem based learning on the pre-service teachers? } \\
\text { critical thinking skills and academic achievement }\end{array}$ & $\mathrm{PhD}$ \\
\hline 29 & MELİH KOÇAKOĞLU & 2008 & $\begin{array}{c}\text { The effect of problem based learning and motivational styles on students' } \\
\text { academic success and attitudes towards biology course }\end{array}$ & $\mathrm{PhD}$ \\
\hline 30 & MERAL DEMIRÖREN & 2008 & $\begin{array}{l}\text { Evaluation of clinical reasoning skill of students in PBL-based-integrated } \\
\text { medical curriculum }\end{array}$ & Master's \\
\hline 31 & VESIFE HATISARU & 2008 & $\begin{array}{l}\text { The influence of problem-based learning method in the success of the ninth } \\
\text { grade math learners and their attitude towards math }\end{array}$ & Master's \\
\hline 32 & FATİH GÜRSUL & 2008 & $\begin{array}{l}\text { The effects of online and face to face problem based learning approaches on } \\
\text { student's academic achievement, their attitudes towards mathematics }\end{array}$ & $\mathrm{PhD}$ \\
\hline 33 & GÖKHAN SERİN & 2009 & $\begin{array}{l}\text { The effect of problem based learning instruction on 7th grade students' } \\
\text { science achievement, attitude toward science and scientific process skills }\end{array}$ & $\mathrm{PhD}$ \\
\hline 34 & AHMET ŞAHBAZ & 2009 & $\begin{array}{l}\text { The attitudes of ELT students towards problem based learning in effective } \\
\text { communication skills classes }\end{array}$ & Master's \\
\hline 35 & EMINE ŞALGAM & 2009 & $\begin{array}{l}\text { The effect of problem based learning method on students' academic } \\
\text { achievement and their attitude for physics lesson }\end{array}$ & Master's \\
\hline 36 & $\begin{array}{l}\text { MUSTAFA SERKAN } \\
\text { GÜNBATAR }\end{array}$ & 2009 & $\begin{array}{l}\text { Effects on creative thinking skills and attitudes of students due to the web } \\
\text { mediated problem based learning. }\end{array}$ & Master's \\
\hline 37 & PINAR AKIN & 2009 & $\begin{array}{c}\text { The effects of problem-based learning on students? success in the teaching } \\
\text { the topic fractions at the } 5 \text { th grade }\end{array}$ & Master's \\
\hline 38 & ASLIHAN KARTAL TAŞOĞLU & 2009 & $\begin{array}{l}\text { The effect of problem based learning on students? achievements, scientific } \\
\text { process skills and attitudes towards problem solving in physics education }\end{array}$ & Master's \\
\hline 39 & SEVGİ TURAN & 2009 & $\begin{array}{c}\text { The relationship between attitudes to problem-based learning, } \\
\text { learning skills and achievement }\end{array}$ & $\mathrm{PhD}$ \\
\hline 40 & DİDEM İNEL & 2009 & $\begin{array}{l}\text { The effects of the using of problem based learning method in science and } \\
\text { technology course on students? the levels of constructing concepts, academic } \\
\text { achievements and enquiry learning skill perceptions }\end{array}$ & Master's \\
\hline 41 & BÜLENT ALAGÖZ & 2009 & $\begin{array}{l}\text { Effect of problem based learning method in promoting environmental } \\
\text { consciousness in candidate social studies teachers }\end{array}$ & $\mathrm{PhD}$ \\
\hline 42 & AYŞEGÜL ARSLAN & 2009 & $\begin{array}{c}\text { The effect of learning style based on problem on the success of student in } \\
\text { studying human and environment unit }\end{array}$ & Master's \\
\hline 43 & TÜLİN ÖZSARI & 2009 & $\begin{array}{l}\text { The effect of cooperative learning method to the fourth grade students' } \\
\text { achievement on mathematic learning: Problem based learning (PBL) and } \\
\text { student teams- achievement division method (STAD) }\end{array}$ & Master's \\
\hline 44 & HAKAN TEKEDERE & 2009 & $\begin{array}{l}\text { The effect of locus of control in web assisted problem based learning (PBL) } \\
\text { on students? success, problem solving skills, and attitudes to learning }\end{array}$ & $\mathrm{PhD}$ \\
\hline 45 & MÜKERREM APAÇIK & 2009 & $\begin{array}{l}\text { The effects of problem-based learning method on 9th grade students' } \\
\text { achievement in geometry }\end{array}$ & Master's \\
\hline 46 & HASAN HÜSEYİN AKBULUT & 2010 & $\begin{array}{l}\text { Implementation and evaluation of problem based learning on buoyant force } \\
\text { and floating concepts }\end{array}$ & Master's \\
\hline 47 & TUĞRUL KAR & 2010 & $\begin{array}{l}\text { The effects of problem-based learning in linear algebra on the academic } \\
\text { achievement, problem-solving skills and creativity of students }\end{array}$ & Master's \\
\hline 48 & NEŞE UYGUN & 2010 & $\begin{array}{c}\text { Effect of the problem based learning on the attitudes, academic achievement } \\
\text { and retention level of the } 5 \text { th year ground school pupils } \\
\text { in the mathematics course }\end{array}$ & Master's \\
\hline 49 & NAZAN YILDIZ & 2010 & $\begin{array}{c}\text { The effect of experiment applications on the success, attitude and scientific } \\
\text { process abilities of the students in the solution of the learning scenarios based } \\
\text { on problems in science education }\end{array}$ & Master's \\
\hline 50 & AYŞEGÜL BAYRAM & 2010 & $\begin{array}{l}\text { The effect of problem based learning on overcoming 5th grade students? } \\
\text { misconceptions about ?heat and temperature? }\end{array}$ & Master's \\
\hline 51 & MESUT KUŞDEMIR & 2010 & $\begin{array}{l}\text { An analysis of the effect of problem based learning model on the students } \\
\text { success, attitude and motivations }\end{array}$ & Master's \\
\hline 52 & CEMAL TOSUN & 2010 & $\begin{array}{c}\text { The effect of problem based learning method on understanding of the } \\
\text { solutions and its? physical properties }\end{array}$ & $\mathrm{PhD}$ \\
\hline 53 & ELİF ÇELİK & 2010 & $\begin{array}{c}\text { The effect of problem based learning approach in science education on } \\
\text { students? academic achievement, attitude, academic risk taking level and } \\
\text { retention of knowledge }\end{array}$ & Master's \\
\hline 54 & ESRA BENLİ & 2010 & $\begin{array}{l}\text { The research of the effects of problem based learning to the permanence of } \\
\text { information, the academic success of science teacher candidates and their } \\
\text { attitudes toward science }\end{array}$ & Master's \\
\hline 55 & AYFER KARADAŞ & 2010 & $\begin{array}{l}\text { Effect of the problem based learning applied to student achievement in } \\
\text { biochemistry to "coenzyme" issue }\end{array}$ & Master's \\
\hline 56 & ALPER ALTUNÇEKICÇ & 2010 & $\begin{array}{c}\text { The effect of web supported problem based learning medium upon cognitive } \\
\text { and effective learning products: Gazi University } \\
\text { Kastamonu Education Example }\end{array}$ & $\mathrm{PhD}$ \\
\hline 57 & ALİ TURAN TOZO & 2011 & $\begin{array}{c}\text { The evaluation of the affect on student success and attitude of the subject } \\
\text { which is Turkey's geopolitical position and regional problems via problem } \\
\text { based learning technique }\end{array}$ & Master's \\
\hline 58 & AYŞE ÇAĞIL KAYIPMAZ & 2011 & $\begin{array}{l}\text { The effects of problem based learning on primary school 5th grade students' } \\
\text { attitudes toward reading }\end{array}$ & Master's \\
\hline
\end{tabular}




\begin{tabular}{|c|c|c|c|c|}
\hline 59 & BILAL DEMIR & 2011 & $\begin{array}{l}\text { The application of problem based learning model } \\
\text { in numerical analysis course }\end{array}$ & Master's \\
\hline 60 & MEHTAP ESKİ & 2011 & $\begin{array}{l}\text { The effect of problem based learning method to the teaching algebraic } \\
\text { expositions and equations in } 7 \text { th classes of primary education }\end{array}$ & Master's \\
\hline 61 & GÜLNUR ÖZDİL & 2011 & $\begin{array}{l}\text { Effects of problem based learning approach on students? success in teaching } \\
\text { the concepts of area and perimeter in seventh grade in primary schools }\end{array}$ & Master's \\
\hline 62 & ADEM AYVACI & 2011 & $\begin{array}{l}\text { The effect of problem-based learning approach on } \\
\text { teaching the concept of equation }\end{array}$ & Master's \\
\hline 63 & KANİ ÜLGER & 2011 & $\begin{array}{l}\text { The effect of problem based learning method to creative thinking } \\
\text { in visual arts education }\end{array}$ & $\mathrm{PhD}$ \\
\hline 64 & ALIME ŞAHİN & 2011 & $\begin{array}{l}\text { To analyze the effect of Problem Based Learning (PBL) Approach on } \\
\text { academic success of students in teaching basic electrical circuits in general } \\
\text { physics laboratory course }\end{array}$ & Master's \\
\hline 65 & PINAR ÇETIN & 2011 & $\begin{array}{l}\text { The effect of problem based learning applications on learning outcomes of } \\
\text { the students in primary education life studies course }\end{array}$ & Master's \\
\hline 66 & HAKAN YILDIRIM & 2011 & $\begin{array}{l}\text { The effect of problem based and project based learning styles on primary } \\
\text { school students? successes and attitude }\end{array}$ & Master's \\
\hline 67 & ÖMER FARUK ÖZEKEN & 2011 & $\begin{array}{c}\text { An investigation of effectiveness of problem based learning } \\
\text { in teaching acid-base subject }\end{array}$ & $\mathrm{PhD}$ \\
\hline 68 & CANAN DİLEK EREN & 2011 & $\begin{array}{l}\text { The effect of problem based learning (PBL) on critical thinking disposition, } \\
\text { concept learning and scientific creative thinking skill in science education }\end{array}$ & $\mathrm{PhD}$ \\
\hline 69 & SEVİNÇ KAÇAR & 2012 & $\begin{array}{c}\text { The effects of problem based learning method integrated visual arts on } \\
\text { students? academic achievements, scientific creativity and attitudes towards } \\
\text { science teaching with art activities }\end{array}$ & Master's \\
\hline 70 & MAHİR BİBER & 2012 & $\begin{array}{c}\text { The influence of affective factors on students' mathematical gains in the } \\
\text { process of problem based learning }\end{array}$ & $\mathrm{PhD}$ \\
\hline 71 & TOLGA ERDOĞAN & 2012 & $\begin{array}{l}\text { The effects of problem-based learning on achievement and } \\
\text { self-regulated learning skills }\end{array}$ & $\mathrm{PhD}$ \\
\hline 72 & AYHAN MORALAR & 2012 & $\begin{array}{l}\text { The effect of problem-based learning approach on academic success, attitude } \\
\text { and motivation in science education }\end{array}$ & Master's \\
\hline 73 & ESEN ERSOY & 2012 & $\begin{array}{l}\text { High-level cognitive thinking skills and the changes in affection acquisitions } \\
\text { in the problem-based learning process }\end{array}$ & $\mathrm{PhD}$ \\
\hline 74 & ELVAN İNCE AKA & 2012 & $\begin{array}{l}\text { The effect of problem-based learning method used for teaching acids and } \\
\text { bases on different variables and students? views on the method }\end{array}$ & $\mathrm{PhD}$ \\
\hline 75 & HATİCE BÜYÜKDOKUMACI & 2012 & $\begin{array}{l}\text { Effects of problem based learning on learning products in science and } \\
\text { technology lesson for elementary 8th grade }\end{array}$ & Master's \\
\hline 76 & AHMET ELBİSTANLI & 2012 & $\begin{array}{l}\text { Investigation of the effect of problem based learning approach on the } \\
\text { achievement, attitude and scientific process skills of 11. grade students } \\
\text { through chemical equilibrium subject }\end{array}$ & Master's \\
\hline 77 & DIDEM İNEL & 2012 & $\begin{array}{l}\text { The effects of concept cartoons-assisted problem based learning on students' } \\
\text { problem solving skills perceptions, motivation toward science learning and } \\
\text { levels of conceptual understanding }\end{array}$ & $\mathrm{PhD}$ \\
\hline 78 & PINAR FETTAHLIOĞLU & 2012 & $\begin{array}{c}\text { The usage of argumentation-based and problem-based learning approaches } \\
\text { intended for developing the environmental literacy } \\
\text { of pre-service science teachers }\end{array}$ & $\mathrm{PhD}$ \\
\hline 79 & HASAN ŞAHIN KIZILCIK & 2012 & $\begin{array}{l}\text { A case study on development of heat and temperature concepts in process of } \\
\text { problem-based learning }\end{array}$ & $\mathrm{PhD}$ \\
\hline 80 & RAMAZAN GÖGÜŞ & 2013 & $\begin{array}{l}\text { Problem based learning teaching science and its effect on students' academic } \\
\text { achievement and attitudes }\end{array}$ & Master's \\
\hline 81 & TUĞBA BARAN & 2013 & $\begin{array}{c}\text { The comparison of problem based learning and expository teaching } \\
\text { approaches in terms of cognitive learning levels }\end{array}$ & Master's \\
\hline 82 & PINAR ÇELIK & 2013 & $\begin{array}{l}\text { The effect of problem based learning on pre-service teachers' physics course } \\
\text { achievement, learning approaches and science process skills }\end{array}$ & $\mathrm{PhD}$ \\
\hline 83 & NESLIHAN USTA & 2013 & $\begin{array}{c}\text { The effectiveness of the problem based learning method on secondary school } \\
\text { students' mathematics achievement, mathematics self-efficacy and problem } \\
\text { solving skills }\end{array}$ & $\mathrm{PhD}$ \\
\hline 84 & NIYAZİ SEZER & 2013 & $\begin{array}{l}\text { Teaching of statistical basic concepts by the } \\
\text { problem-based learning approach }\end{array}$ & Master's \\
\hline 85 & RUKIYE MERHAMETLİ & 2013 & $\begin{array}{l}\text { Application of the teaching of 'surface tension of liquids' onto problem based } \\
\text { learning model (PBL): An experimental study }\end{array}$ & Master's \\
\hline 86 & MEHMET ALUS & 2013 & $\begin{array}{l}\text { The effect of problem based learning method on the academic achievement of } \\
\text { secondary school students in math }\end{array}$ & Master's \\
\hline 87 & AYŞE TUĞBA TETİK & 2013 & $\begin{array}{l}\text { The effect of problem-based learning method on the decision-making skills of } \\
\text { students at the social studies lesson }\end{array}$ & Master's \\
\hline 88 & MUKADDER BARAN & 2013 & $\begin{array}{c}\text { The effect of context- and problem-based learning } \\
\text { on teaching thermodynamics }\end{array}$ & $\mathrm{PhD}$ \\
\hline
\end{tabular}




\begin{tabular}{|c|c|c|c|c|}
\hline 89 & BÜŞRA KUZEY & 2013 & $\begin{array}{c}\text { Investigation of effectiveness of problem based learning (PBL) model on } \\
\text { teaching of the subject of chemical kinetics }\end{array}$ & Master's \\
\hline 90 & MUSTAFA COŞAR & 2013 & $\begin{array}{c}\text { Effects of computer programming studies on academic success, critical } \\
\text { thinking skills and programming-based attitudes } \\
\text { in problem-based learning environment }\end{array}$ & $\mathrm{PhD}$ \\
\hline 91 & ERKAN ÖZCAN & 2013 & $\begin{array}{c}\text { Effects of problem based learning on prospective science teachers' problem } \\
\text { solving skills, academic achievements and attitudes }\end{array}$ & Master's \\
\hline 92 & SERDAR SAVAŞ & 2013 & $\begin{array}{c}\text { The effects of the use of problem based learning at seventh grade on students' } \\
\text { attitude and achievement in Turkish courses }\end{array}$ & $\mathrm{PhD}$ \\
\hline 93 & BURCU ÇOBAN & 2014 & $\begin{array}{c}\text { The effects of problem based learning to success, } \\
\text { creativity and transfer skills of the students }\end{array}$ & Master's \\
\hline 94 & TUFAN İNALTEKIN & 2014 & $\begin{array}{l}\text { The impact of problem based learning (PBL) practices on pedagogical } \\
\text { content knowledge (PCK) development of pre-service science teachers. }\end{array}$ & $\mathrm{PhD}$ \\
\hline 95 & GÜLCAN UYAR & 2014 & $\begin{array}{l}\text { The effects of problem based learning technique on sixth grade students' } \\
\text { academic achievement and attitudes toward mathematics course }\end{array}$ & Master's \\
\hline 96 & BELMA ARSLAN TURAN & 2014 & $\begin{array}{l}\text { Effects of problem-based learning on achievement, self-regulated learning } \\
\text { skills and academic self-concept }\end{array}$ & $\mathrm{PhD}$ \\
\hline 97 & OZAN EMRE DEMIREL & 2014 & $\begin{array}{l}\text { Effects of problem based learning and argumentation based learning on the } \\
\text { students' chemistry achievement, their science process skills and science } \\
\text { reasoning aptitudes }\end{array}$ & Master's \\
\hline 98 & MUSTAFA ONUR YURDAL & 2015 & $\begin{array}{l}\text { The relationship between faculty of medicine students' attitudes toward } \\
\text { problem based learning and self-directed learning readiness }\end{array}$ & Master's \\
\hline 99 & MAKBULE KELEŞ & 2015 & $\begin{array}{l}\text { The effect of problem-based learning method on student' recall level and } \\
\text { success in the processing of Science and Technology course }\end{array}$ & Master's \\
\hline 100 & TUĞÇE TUNÇ & 2015 & $\begin{array}{c}\text { The effect of problem based learning on students' academic achievements in } \\
\text { the subject of Electrochemistry in Analytical Chemistry course }\end{array}$ & $\mathrm{PhD}$ \\
\hline 101 & MERVE OLÇA & 2015 & $\begin{array}{l}\text { The effects of problem based learning method on students' analytical thinking } \\
\text { skills, conceptual understandings and attitudes toward science }\end{array}$ & Master's \\
\hline
\end{tabular}

\section{Appendix B}

Final Version of Dissertation Classification Form (DCF)

\begin{tabular}{|c|c|c|c|}
\hline \multicolumn{4}{|c|}{ Dissertation Identity Tag } \\
\hline \multicolumn{4}{|l|}{ Name } \\
\hline \multicolumn{4}{|l|}{ Author } \\
\hline \multicolumn{4}{|l|}{ Publication Year } \\
\hline \multicolumn{4}{|l|}{ CoHE Publication ID No } \\
\hline Main Category & \multicolumn{3}{|r|}{ Sub-Categories } \\
\hline Type of Study & • & $\begin{array}{l}\text { Master's } \\
\text { Doctorate }\end{array}$ & \\
\hline Research Learning Domain & & $\begin{array}{l}\text { Science (Mathematics, bi } \\
\text { and communication techn } \\
\text { Social Studies (Social sci } \\
\text { communication skills) } \\
\text { Language Arts } \\
\text { Fine Arts (Visual arts, pia }\end{array}$ & $\begin{array}{l}\text { ry, physics, life sciences, science and technology, information } \\
\text { hy, environmental education, classroom management, effective }\end{array}$ \\
\hline Research Method & & $\begin{array}{l}\text { Quantitative } \\
\text { Quantitative \& Qualitativ }\end{array}$ & \\
\hline Research Design & $\bullet$ & $\underline{-}$ & \\
\hline Research Domain & & $\begin{array}{l}\text { Cognition } \\
\text { Affect } \\
\text { Cognition \& Affect }\end{array}$ & $\begin{array}{ll}- & \text { Cognition \& Conation } \\
- & \text { Cognition, Affect \& Conation }\end{array}$ \\
\hline Subject Group & & $\begin{array}{l}\text { Elementary Education } \\
\text { Secondary Education }\end{array}$ & $\begin{array}{ll} & \text { Higher Education } \\
\text { - } & \text { Teacher Education }\end{array}$ \\
\hline Subject Group Size & & $\begin{array}{l}1-40 \\
41-80\end{array}$ & $\begin{array}{ll}- & 81-120 \\
\text { - } & 120 \text { and above }\end{array}$ \\
\hline Length of Treatment & $\bullet$ & Weeks & \\
\hline Data Collection Instrument(s) & $\bullet$ & 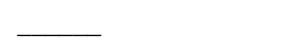 & \\
\hline
\end{tabular}




\section{REFERENCES}

[1] D'Angelo, C. M., Touchman, S., \& Clark, D. B. (2009). Constructivism. In E. M. Anderman, \& L. H. Anderman (Ed.) Psychology of Classroom Learning: An Encyclopedia. USA: Gale, Cengage Learning.

[2] Savery, J. R. (2006). Overview of problem-based learning: Definitions and distinctions. Interdisciplinary Journal of Problem-based Learning, 1(1), 9-20.

[3] Walker, A., \& Leary, H. M. (2009). A problem based learning meta-analysis: Differences across problem types, implementation types, disciplines, and assessment levels. Interdisciplinary Journal of Problem Based Learning, 3(1), $12-43$.

[4] Albanese, M.A., Mitchell, S. (1993). Problem-based Learning: A review of literature on its outcomes and implementation issues. Academic Medicine, 68(1), 52-81.

[5] Berkson, L. (1993). Problem-based learning: Have the expectations been met? Academic Medicine, 68(10), 79-88.

[6] Colliver, J. A. (2000). Effectiveness of problem-based learning curricula: Research and theory. Academic Medicine, 75(3), 259-266.

[7] [7] Dochy, F., Segers, M., Van den Bossche, P., \& Gijbels, D. (2003). Effects of problem-based learning: A meta-analysis. Learning and Instruction, 13(5), 533-568.

[8] Gijbels, D., Dochy, F., Van den Bossche, P., \& Segers, M. (2005). Effects of problem-based learning: A meta-analysis from the angle of assessment. Review of Educational Research, 75(1), 27-61.

[9] Kalaian, H. A., Mullan, P. B., \& Kasim, R. M. (1999). What can studies of problem-based learning tell us? Synthesizing and modelling PBL effects on National Board of Medical Examination Performance: Hierarchical linear modelling meta-analytic approach. Advances in Health Sciences Education, 4(3), 209-221.

[10] Leary, H. M. (2012). Self-Directed Learning in Problem-Based Learning Versus Traditional Lecture-Based Learning: A Meta-Analysis. Unpublished doctoral thesis, Utah State University.

[11] Loyens, S. M. M., Magda, J., \& Rikers, R. M. J. P. (2008). Self-directed learning in problem-based learning and its relationships with self-regulated learning. Educational Psychology Review, 20(4), 411-427.

[12] Vernon, D. T., \& Blake, R. L. (1993). Does problem-based learning work? A meta analysis of evaluative research. Academic Medicine, 68(7), 550-563.

[13] Üstün, U. (2012). To What Extent is Problem-Based Learning Effective as Compared to Traditional Teaching in Science Education? A Meta-Analysis Study. Unpublished doctoral thesis, Middle East Technical University.

[14] Strobel, J., \& van Barneveld, A. (2009). When is PBL more effective? A meta-synthesis of meta-analyses comparing PBL to conventional classrooms. Interdisciplinary Journal of Problem-Based Learning, 3(1), 44-58.
[15] Savery, J. R., \& Duffy, T. M. (1995). Problem-based learning: An instructional model and its constructivist framework. Educational Technology, 35(5), 31-38.

[16] Barrows, H. S. (1996). Problem-based learning in medicine and beyond: A brief overview. New Directions for Teaching and Learning, 68, 3-12.

[17] Barrows, H. S. (1998). The essentials of problem-based learning. Journal of Dental Education, 62(9), 630-633.

[18] Hmelo-Silver, C. E. (2004). Problem-based learning: What and how do students learn? Educational Psychology Review, $16(3), 235-266$.

[19] Barrows, H. S. (1986). A taxonomy of problem-based learning methods. Medical Education, 20(6), 481-486.

[20] Huitt, W., \& Cain, S. (2005). An overview of the conative domain. Retrieved October 2012, http://teach.valdosta.edu/whuitt/brilstar/chapters/conative.do c.

[21] Das Carlo, M., Swadi, H., \& Mpofu, D. (2003). Medical student perceptions of factors affecting productivity of problem-based learning tutorial groups: Does culture influence the outcome? Teaching and Learning in Medicine, 15(1), 59-64.

[22] Dickie, C., \& Jay, L. (2010). Innovation in postgraduate teaching: Mixed methods to enhance learning and learning about learning. Higher Education Research \& Development, 29(1), 29-43.

[23] Downing, K., Kwong, T., Chan, S.-W., Lam, T.-F., \& Downing, W. K. (2009). Problem-based learning and development of metacognition. Higher Education, 57(5), 609-621.

[24] Elsie, M., Francis, B., \& Gonzaga, M. A. (2009). Attitudes and perceptions of students and teachers about problem based learning in radiography curriculum at Makerere University, Uganda. European Journal of Radiography, 1(4), 156-162.

[25] Gibbings, P., Lidstone, J., \& Bruce, C. (2015). Students' experience of problem-based learning in virtual space. Higher Education Research \& Development, 34(1), 74-88.

[26] Kivela, J., \& Kivela, R. J. (2005). Student perceptions of an embedded problem-based learning instructional approach in a hospitality undergraduate programme. International Journal of Hospitality Management, 24(3), 437-464.

[27] Kumar, M., \& Kogut, G. (2006). Students' perceptions of problem-based learning. Teacher Development, 10(1), 105-116.

[28] Pepper, C. (2010). 'There's a lot of learning going on but NOT much teaching!': Student perceptions of problem-based Learning in science. Higher Education Research \& Development, 29(6), 693-707.

[29] Rissi, J.R. (2010). Efficacy of problem based learning in a high school science classroom. Unpublished master's thesis, Michigan State University.

[30] Galand, B., Bentein, B., Bourgeois, K., \& Frenay, E. M. (2005). The effect of a PBL curriculum on students' motivation and self-regulation. Retrieved October 2016, https://halshs.archives-ouvertes.fr/halshs-00603489. 
[31] Krippendorff, K. (2004). Content Analysis: An Introduction to Its Methodology (2nd ed.). Thousand Oaks, CA: Sage

[32] Cohen, L., Manion, L., \& Morrison, K. (2007). Research Methods in Education, (6th Edition). London and New York: Taylor \& Francis Group or Routledge.

[33] Sözbilir, M., \& Kutu, H. (2008). Development and current status of science education research in Turkey. Essays in Education [Special Issue], 1-22.

[34] Erdogan, T., \& Senemoglu, N. (2014). Problem-based learning in teacher education: Its promises and challenges. Procedia-Social and Behavioral Sciences, 116, 459-463.

[35] Van den Hurk, M. M., Wolfhagen, I. H. A. P., Dolmans, D. J. H. M. \& Van der Vleuten, C. P. M. (1999). The impact of student-generated learning issues on individual study time and academic achievement. Medical Education, 33(11), 808-814.

[36] Barrows, H. S. \& Tamblyn, R. M. (1980). Problem-Based Learning: An Approach to Medical Education. New York: Springer Publishing.

[37] Schmidt, H. G., Vermeulen, L. \& Van Der Molen, H. T. (2006). Long-term effects of problem-based learning: a comparison of competencies acquired by graduates of a problem-based and a conventional medical school. Medical Education, 40(6), 562-567.
[38] Kaya, A. (2008). A comparison of the classroom management approaches of the class teachers implementing constructivist learning approach and those of the branch teachers not implementing this approach (A case study in Gaziantep). Unpublished doctoral thesis, İnönü University.

[39] Özsevgeç, T., \& Karamustafaoğlu, S. (2010). Pre-service student teachers' profiles of the measurement-assessment approaches. Journal of Turkish Educational Sciences, 8(2), 333-354.

[40] Gür, T., Dilci, T., \& Arseven, A. (2009). The opinions of pre-service teachers in transition from traditional approach to constructivism: A discourse analysis. Dergi Karadeniz, 17. Accessed May 2017, http://dergipark.ulakbim.gov.tr/.

[41] Aygören, F. (2009). Evaluating the constructivist learning environments by the views of the primary school teachers and school administrators (Sample of Çine). Unpublished master's thesis, Adnan Menderes University.

[42] Duch, B. J. (2001). Models for Problem-Based Instruction in Undergraduate Courses. In B. J. Duch, S. E. Groh, \& D. E. Allen (Ed.) The Power of Problem-Based Learning: A Practical "How to" for Teaching Undergraduate Courses in Any Discipline (pp. 39-45). Virginia, USA: Stylus Publishing. 